\title{
Tingkat Pengetahuan Masyarakat Tentang Penanganan Henti Jantung di Wilayah Jakarta Utara
}

\author{
Rahma Hidayati ${ }^{\mathrm{a}}$ \\ ${ }^{a} A$ kademi Keperawatan Bina Insan, Jakarta Utara, 14260, Indonesia \\ Email korespondensi : hidayati.rahma@gmail.com
}

\begin{abstract}
Cardiac Arrest is one of the most common conditions of emergency in the public. First aid from first responder can prevent the risk of death and disability. The public knowledge in handling the emergency on cardiac arrest is necessary to investigate because knowledge is the basis for taking action. Many incidents of cardiac arrest in the community that cannot be saved because of their ignorance to provide emergency response. This research aims at identifying the public knowledge in the handling of cardiac arrest emergency. This research applies an analytical-descriptive method with number of respondents involved of 250 persons selected randomly based on a cluster sampling technique. The data collected uses a questionnaire and analysis with a Univariate and bivariate Statistics. The results shows that $55.6 \%$ respondents have low knowledge on handling the cardiac arrest emergency. There was a significant relationship between level of knowledge with education level, sources information and BLS training experience. Within the interval estimation of $95 \%$, the respondent's knowledge varies from 13.48 to 14.07 (low). Further research can be done by additional the region coverage and developing aspects of BLS attitudes and skills.
\end{abstract}

Keywords : Basic Life Support, cardiac arrest, knowledge

\begin{abstract}
Abstrak
Henti jantung merupakan salah satu keadaan gawat darurat yang sering terjadi di masyarakat. Pertolongan pertama dari first responder dapat mencegah resiko kematian dan kecacatan. Pengetahuan masyarakat tentang penanganan henti jantung penting diteliti, karena pengetahuan merupakan dasar dalam melakukan tindakan. Banyak kejadian henti jantung di masyarakat yang tidak dapat diselamatkan dikarenakan ketidaktahuan mereka untuk memberikan respon kegawatdaruratan. Tujuan penelitian ini adalah mengidentifikasi pengetahuan masyarakat dalam penanganan kegawatdaruratan henti jantung. Metode yang digunakan adalah deskriptif analitik dengan jumlah responden 250 orang yang dipilih melalui tekhnik cluster random sampling. Pengumpulan data dilakukan menggunakan kuesioner dan dianalisa dengan statistik univariat dan bivariat. Hasil penelitian menunjukkan 55,6\% responden memiliki tingkat pengetahuan yang rendah tentang penanganan henti jantung. Tingkat pengetahuan responden memiliki hubungan dengan tingkat pendidikan, sumber informasi dan keikutsertaan dalam pelatihan Bantuan Hidup Dasar (BHD). Dengan estimasi interval 95\%, pengetahuan responden berada pada angka 13,48 - 14,07 (rendah). Penelitian lanjutan dapat dilakukan dengan penambahan cakupan wilayah dan pengembangan pada aspek sikap serta keterampilan BHD
\end{abstract}

Kata Kunci : Bantuan hidup dasar, henti jantung, pengetahuan

\section{PENDAHULUAN}

Henti nafas dan atau henti jantung (cardiac arrest) merupakan kondisi kegawatdaruratan medik yang harus segera mendapatkan penanganan baik dari petugas medis maupun masyarakat sekitar kejadian. Henti jantung sering terjadi saat pasien berada di luar lingkungan rumah sakit atau disebut juga Out of Hospital Cardiac Arrest (OHCA). Menurut layanan gawat darurat medis, sekitar 420.000 orang
Amerika mengalami serangan jantung saat mereka berada di rumah atau tempat umum lainnya. Penelitian sebelumnya juga menemukan hal yang sama yaitu sekitar 360.000 orang mengalami serangan jantung saat mereka berada di rumah atau tempat umum lainnya. Dari jumlah tersebut, hanya $33 \%$ saja yang mendapatkan pertolongan pertama oleh masyarakat awam terlatih (Go, et al, 2014 ; Sasson et al, 2013). 
Di Indonesia hingga saat ini belum ada data statistik mengenai OHCA, akan tetapi prevalensi penyakit jantung di Indonesia mencapai 1,5 persen dari total penduduk. Penelitian tersebut juga menunjukkan penderita penyakit jantung koroner cenderung lebih banyak dialami penduduk perkotaan. Data Sample Registration System (SRS) Indonesia tahun 2018 juga menyebutkan penyakit jantung merupakan penyebab kematian tertinggi pertama di Indonesia (Badan Litbangkes berdasarkan Riskesdas, 2018 ; Usman , dkk, 2019)

Setiap orang, baik medis maupun masyarakat awam (Bystander) bisa saja menjadi first responder di tempat kejadian. Penanganan yang terlambat atau tidak tepat pada henti jantung akan mengakibatkan kematian dalam hitungan menit. Sebaliknya pasien OHCA yang segera dilakukan resusitasi jantung, memiliki kesempatan bertahan hidup lebih besar. Kembalinya sirkulasi spontan dalam jangka waktu kurang dari 20 menit setelah henti jantung memiliki asosiasi positif terhadap angka survival pasien OHCA (Berdowski, Berg, Tijssen, \& Koster, 2010; Wibrandt, Norsted, Schmidt, \& Schierbeck, 2015).

Resusitasi jantung paru (RJP) merupakan suatu tindakan darurat dan menjadi bagian utama dalam melakukan bantuan hidup dasar (BHD). Selama ini RJP diberikan mengacu pada algoritma standar yang ditetapkan oleh American Hearth Association (Resuscitation Council, 2015). RJP bertujuan untuk mengembalikan keadaan henti jantung dan atau henti nafas agar kembali berfungsi optimal (Muttaqin, 2009). Sekitar 40,1 \% pasien OHCA terselamatkan setelah dilakukan resusitasi jantung paru oleh bystander (American Hearth Association, 2015 ; Perkins, et al. 2015).

Selain resusitasi, aspek BHD lainnya yang penting diketahui oleh masyarakat awam adalah pengenalan tanda henti jantung dan aktivasi sistem tanggap darurat. Hal inilah yang menjadi tujuan penelitian ini, yaitu untuk memperoleh gambaran pengetahuan masyarakat dalam penanganan kegawatdaruratan henti jantung.

\section{METODE}

Penelitian ini merupakan penelitian deskriptif dengan jumlah sampel penelitian sebanyak 250 orang. Data diambil dengan menggunakan tekhnik cluster random sampling di wilayah Cilincing Jakarta Utara. Cluster penelitian adalah lima kelurahan yang dipilih melalui tekhnik sampel acak. Selanjutnya beberapa subjek dari tiap cluster dipilih sebagai sampel secara random. Kriteria inklusi sampel adalah masayarakat di wilayah Jakarta Utara, berusia antara 18-65 tahun, bisa baca tulis dan menyatakan bersedia menjadi responden.

Variabel bebas dalam penelitian ini adalah usia, tingkat pendidikan, jenis kelamin, sumber informasi, keikursertaan dalam pelatihan, minat untuk belajar dan keinginan menolong korban. Sedangkan variabel terikatnya adalah tingkat pengetahuan masyarakat. Untuk menilai variabel bebas digunakan kuesioner yang disusun terstruktur berupa isian dan pertanyaan singkat. Sedangkan variabel terikat dikumpulkan melalui kuesioner yang disusun menggunakan pendekatan Standar AHA tahun 2015. Kuesioner terdiri dari 26 item yang disusun menggunakan skala Guttman (Benar-Salah dan Pernah-Tidak pernah). Variabel tingkat pengetahuan dibagi menjadi tiga tingkatan. Pengetahuan dikategorikan baik apabila mampu menjawab benar $\geq 75 \%$, (total jawaban benar $\geq 20$ soal), kategori sedang apabila mampu menjawab benar 56-75 \% (total jawaban benar 15-19 soal) dan kategori kurang apabila jawaban benar $\leq$ $75 \%$ (total jawaban benar $\leq 14$ soal).

Analisis statistik dilakukan secara univariat dan bivariat. Analisis univariat dilakukan untuk melihat data demografi serta tingkat pengetahuan responden. 
Terdapat 8 variabel yang dianalisis univariat yaitu usia, tingkat pendidikan, jenis kelamin, sumber informasi, keikursertaan dalam pelatihan, minat untuk belajar, keinginan menolong dan tingkat pengetahuan responden. Sedangkan analisis bivariat dilakukan untuk melihat hubungan antara tingkat pengetahuan dengan masingmasing variabel bebas. Uji statistik yang digunakan dalam analisis bivariat adalah Chi Square.

\section{HASIL}

Penelitian ini telah dilaksanakan di dua kecamatan di wilayah Jakarta Utara. Hasil analisis univariat pada variabel bebas serta variabel terikat dijabarkan dalam Tabel 1.

Tabel 1. Distribusi responden menurut karakteristik dan variabel independen $(\mathrm{n}=250)$

\begin{tabular}{lcc}
\multicolumn{1}{c}{ Variabel } & Frekuensi & \% \\
\hline Usia & & \\
- $18-40$ Tahun & 164 & 65,6 \\
- 41-59 Tahun & 71 & 28,4 \\
- $\quad$ 60 Tahun & 15 & 6 \\
\hline Jenis Kelamin & & \\
- Laki-laki & 101 & 40,4 \\
- Perempuan & 149 & 59,6 \\
\hline Pendidikan : & & \\
- Dasar & 112 & 44,8 \\
- Menengah & 115 & 46 \\
- Tinggi & 23 & 9,2 \\
\hline Sumber Informasi BHD & & \\
- Belum tahu & 133 & 53,2 \\
- Anggota Keluarga & 20 & 8,0 \\
- Televisi & 40 & 16,0 \\
- Tenaga Kesehatan & 24 & 9,6 \\
- Media cetak/online & 33 & 13,2 \\
\hline Pelatihan BHD & & \\
- Tidak pernah & 238 & 95,2 \\
- Pernah & 12 & 4,8 \\
\hline
\end{tabular}

\begin{tabular}{|c|c|c|}
\hline Variabel & Frekuensi & $\%$ \\
\hline \multicolumn{3}{|c|}{ Minat mempelajari BHD: } \\
\hline - Sangat Besar & 169 & 67,6 \\
\hline - Sedang & 72 & 28,8 \\
\hline - Tidak berminat & 9 & 3,6 \\
\hline \multicolumn{3}{|c|}{ Keinginan menolong korban: } \\
\hline - Sangat besar & 191 & 76,4 \\
\hline - Biasa & 52 & 20,8 \\
\hline - Tidak berminat & 7 & 2,8 \\
\hline
\end{tabular}

Hasil analisis univariat pada Tabel 1 menjelaskan bahwa responden terbanyak berusia antara 18-40 tahun $(65,6 \%)$ dan berjenis kelamin perempuan (59.6\%), dengan tingkat pendidikan terbanyak adalah pendidikan menengah/SMA (46\%). Sebagian besar responden belum pernah mengetahui tentang BHD (53,2 \%). Sumber informasi tentang tatalaksana henti jantung/BHD sebagian besar didapatkan melalui televisi (16\%). Sebagian besar responden juga belum pernah ikut dalam pelatihan BHD $(95,2)$. Mayoritas responden juga memiliki minat yang sangat besar $(67,6 \%)$ untuk mempelajari tata laksana henti jantung/BHD serta sangat ingin memberikan pertolongan pada korban henti jantung setelah mereka mempelajari tekhnik BHD (76,4\%).

Tabel 2. Distribusi responden berdasarkan tingkat pengetahuan $(\mathrm{n}=250)$

\begin{tabular}{ccc}
\hline \multicolumn{1}{c}{ Variabel } & Jumlah & Persentase (\%) \\
\hline Tingkat pengetahuan & & \\
Rendah/kurang & 139 & 55,6 \\
Cukup & 90 & 36 \\
Baik & 21 & 8,4 \\
\hline
\end{tabular}

Hasil uji statistik terhadap tingkat pengetahuan pada tabel 2, menjelaskan bahwa sebagian besar responden $(55,6 \%)$ masih memiliki tingkat pengetahuan yang kurang/rendah tentang tatalaksana henti jantung 
Tabel 3. Distribusi responden berdasarkan variabel dependen dan independen $(n=250)$

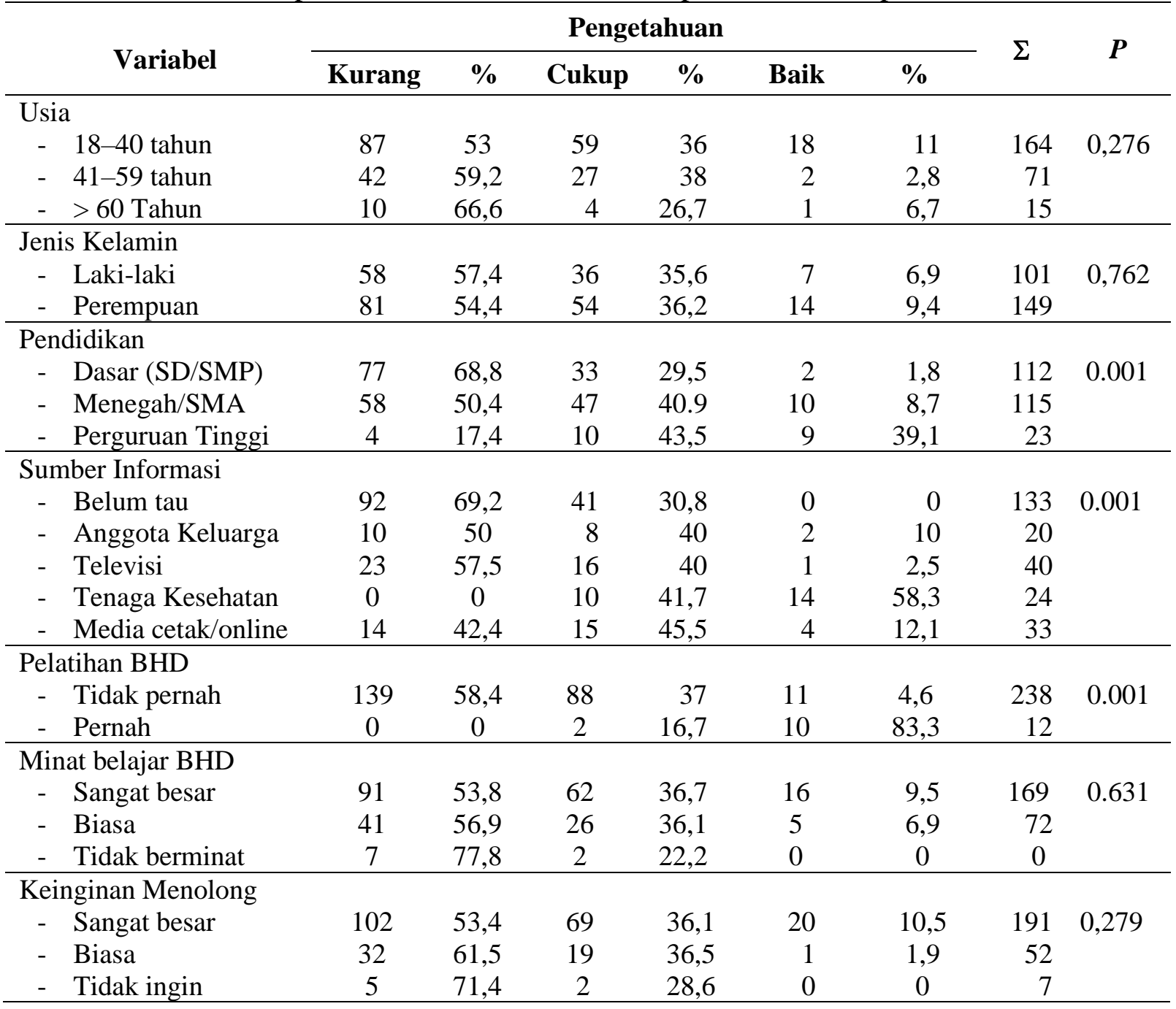

Analisis bivariat dilakukan dengan uji statistik Chi-Square. Hasil analisis menunjukkan bahwa tingkat pengetahuan masyarakat tentang BHD dipengaruhi oleh tingkat pendidikan, sumber informasi dan pengalaman mengikuti pelatihan $(p<0,005)$. Hasil analisis tidak menemukan hubungan bermakna antara tingkat pengetahuan dengan usia, jenis kelamin, keinginan belajar dan keinginan menolong korban. (tabel 3)

\section{PEMBAHASAN}

Pengetahuan adalah informasi yang diketahui dan dapat dipelajari secara umum. Peningkatan pengetahuan tidak selalu menyebabkan perubahan perilaku tetapi pengetahuan sangat penting diberikan sebelum suatu tindakan dilakukan. Perilaku yang didasari oleh pengetahuan biasanya akan bertahan lebih lama dibandingkan dengan yang tanpa pengetahuan. Tinggi atau rendahnya pengetahuan seseorang dipengaruhi oleh beberapa faktor antara lain : usia, pendidikan, pengalaman dan informasi (Notoadmodjo 2012).

Pada penelitian ini, lebih dari setengah responden $(65,6 \%)$ berusia $18-40$ tahun. Usia tersebut termasuk kategori dewasa muda yang secara kognitif telah mampu memecahkan masalah yang kompleks dengan kapasitas berpikir abstrak, logis, dan rasional. Semakin bertambahnya usia maka akan semakin berkembang pula daya tangkap dan pola pikir individu, sehingga siap dan matang 
untuk menerima informasi baru (Dariyo, 2008; Notoatmodjo, 2012). Meskipun responden terbanyak adalah kelompok berusia muda, namun tidak ditemukan hubungan bermakna antara usia dengan tingkat pengetahuan. Hal ini sesuai dengan penelitian Lumangkun, Kumaat dan Rompas (2014) tentang hubungan karakteristik polisi lalu lintas dengan tingkat pengetahuan BHD. Pengetahuan seseorang tidak hanya dipengaruhi oleh usia tetapi juga dipengaruhi faktor lain seperti pendidikan, pengalaman dan informasi (Notoadmodjo 2012).

Salah satu informasi yang penting diketahui masyarakat adalah tentang bantuan hidup dasar (BHD). Hasil penelitian ini menunjukkan bahwa sebagian besar $(55,6 \%)$ masyarakat masih memiliki tingkat pengetahuan yang rendah tentang BHD bagi korban henti jantung. Hasil penelitian ini mendukung penelitian yang dilakukan oleh Ozbilgin, Akan, Hanc1, Aygün, \& Kuvaki (2015) dimana 58,5\% bystanders tidak mengetahui cara melakukan resusitasi jantung. Hasil penelitian ini berbeda dengan penelitian yang dilakukan oleh Erawati (2015) yang menemukan bahwa sebagian besar $(52,8 \%)$ masyarakat di Jakarta Selatan memiliki pengetahuan yang baik tentang Bantuan Hidup Dasar. Meskipun populasi penelitian ini diambil di wilayah yang sama (DKI Jakarta), namun perbedaaan hasil dapat disebabkan adanya perbedaan karakteristik sampel di dua wilayah tersebut. Pada penelitian ini, responden berpendidikan SLTA dan perguruan lebih sedikit dibanding penelitian sebelumnya yang dilakukan di Jakarta selatan. Hal ini juga didukung oleh data Badan Pusat Statistik DKI Jakarta (2010) yang menyatakan jumlah penduduk berpendidikan SMU ke atas lebih banyak di Jakarta selatan dibandingkan Jakarta Utara.

Tingkat pendidikan mempengaruhi tingkat pengetahuan. Menurut Notoatmodjo (2012), semakin tinggi pendidikan seseorang, semakin mudah ia memahami hal-hal baru dan persoalan yang terkait. Hasil penelitian ini menunjukkan ada hubungan pendidikan dengan tingkat pengetahuan BHD pada masyarakat ( $p: 0,01)$. Hal ini sejalan dengan penelitian yang dilakukan oleh Wijaya, Dewi \& Yudhawati (2016) bahwa pendidikan mempengaruhi tingkat pengetahuan masyarakat Denpasar tentang BHD. Meskipun pada penelitian ini, masyarakat yang memiliki pengetahuan baik tentang BHD hanya 21 orang $(8,4 \%)$ namun 90,5 $\%$ dari jumlah tersebut merupakan responden dengan tingkat pendidikan SMA dan perguruan tinggi. Masyarakat dengan pendidikan tinggi juga memiliki ketertarikan untuk mempelajari tekhnik BHD dan resusitasi jantung (Hung, Lui, Lee, Shiu, \& Choi (2014).

Pada penelitian ini tingkat pengetahuan juga dipengaruhi oleh sumber informasi yang didapat. Sumber informasi tentang BHD terbanyak didapatkan responden melalui media televisi (36\%). Sejalan dengan itu, penelitian Erawati (2015) juga menemukan bahwa 48,8\% masyarakat mendapatkan informasi BHD melalui media elektronik. Informasi tentang BHD juga dapat diberikan melalui media visual lainnya seperti video. Kemampuan bystander melakukan kompresi saat resusitasi jantung mengalami peningkatan setelah menonton video singkat tentang BHD (Benoit et al, 2017). Selain media visual, tenaga kesehatan harusnya dapat menjadi sumber informasi populer lainnya. Secara teori, tenaga kesehatan memiliki keilmuan lebih tentang BHD, namun pada penelitian ini hanya 9,6 \% yang mendapatkan informasi BHD dari tenaga kesehatan. Hasil ini dapat disebabkan masih terbatasnya jumlah petugas kesehatan yang melakukan edukasi tentang BHD pada masyarakt awam. Rendahnya peran petugas kesehatan sebagai sumber informasi BHD pada masyarakat, merupakan sesuatu yang perlu ditindaklanjuti dalam penelitian selanjutnya. 
Pengalaman mengikuti pelatihan juga mempengaruhi tingkat pengetahuan masyarakat tentang BHD. Pelatihan merupakan pendidikan non formal untuk meningkatkan pengetahuan. Hasil penelitian ini menunjukkan ada hubungan tingkat pengetahuan dan pengalaman mengikuti pelatihan BHD ( $p$ 0,001). Setiap orang perlu mendapat pelatihan BHD karena kejadian serangan jantung terbanyak terjadi di luar rumah sakit (American Hearth Association, 2015). Seseorang yang pernah mendapatkan pelatihan memiliki pengetahuan yang tinggi tentang tanda dan prosedur henti jantung (Ozbilgin, Akan, Hanc1, Aygün, \& Kuvaki, 2015 ; Qara, Alsulimani, Fakeeh, \& Bokhary, 2019). Jumlah responden yang pernah mendapat pelatihan BHD pada penelitian ini hanya $4,8 \%$. Hasil ini mendukung penelitian sebelumnya yang juga menemukan minimnya jumlah masyarakat yang pernah mengikuti pelatihan BHD. Hal ini berbeda jika dibandingkan dengan beberapa negara lainnya, dimana tingkat partisipasi masyarakat untuk mengikuti pelatihan BHD bervariasi antara 21\%-79\% (Sipsma, Stubbs, \& Plorde, 2011 ; Qara, Alsulimani, Fakeeh, \& Bokhary, 2019). Perbedaan ini dapat disebabkan masih rendahnya motivasi masyarakat serta belum adanya aturan seperti wajib ikut pelatihan BHD di Turki dan Slovenia. Di sana, pelatihan BHD merupakan persyaratan wajib sebelum mendapatkan SIM atau sebelum mendaftar bekerja. BHD dapat dikenalkan sedini mungkin baik melalui pelatihan atau pun cara lainnya. Bentuk kegiatan pelatihan kelas maupun non-kelas tentang BHD memberikan hasil yang sama-sama efektif bagi bystanders (Cross et al, 2019).

Keinginan untuk mengikuti pelatihan dan melakukan BHD tidak selalu diikuti dengan pengetahuan kognitif yang baik (Riggs, Franklin, \& Saylany, 2019). Dalam penelitian ini jumlah responden yang berminat mengikuti pelatihan dan mempunyai kemauan melakukan BHD cukup tinggi, namun hal tersebut tidak mempunyai hubungan bermakna terhadap tingkat pengetahuan. Hal ini bertolak belakang dengan hasil penelitian Maulidia \& Laora (2019) bahwa tingkat pengetahuan kognitif berhubungan dengan kemauan melakukan resusitasi jantung paru. Kemauan melakukan BHD tidak hanya ditentukan oleh faktor kognitif. Beberapa faktor yang berpengaruh adalah: adanya rasa takut salah saat tindakan, serta siapa yang menjadi korban, jenis bantuan nafas yang diberikan (Qara, Alsulimani, Fakeeh, \& Bokhary, 2019 ; Maulidia \& Laora (2019).

\section{KESIMPULAN}

Berdasarkan hasil penelitian dan pembahasan mengenai gambaran pengetahuan masyarakat tentang penanganan henti jantung, dapat disimpulkan bahwa sebagian besar masyarakat Jakarta Utara memiliki tingkat pengetahuan yang rendah tentang Bantuan Hidup Dasar (BHD). Selain itu juga ditemukan tiga faktor yang mempengaruhi tingkat pengetahuan masyarakat yaitu: tingkat pendidikan, sumber informasi dan pengalaman mengikuti pelatihan BHD.

Minimnya pengetahuan masyarakat, dapat dijadikan bahan evaluasi dan rencana kerja lanjutan bagi tenaga kesehatan untuk meningkatkan pengetahuan dan keterampilan masyarakat tentang tatalaksana henti jantung. Seringnya kejadian henti jantung saat seseorang berada di luar rumah sakit dapat dijadikan alasan untuk mengembangkan suatu kegiatan baik dalam bentuk pelatihan maupun non pelatihan. Selain itu penelitian ini juga dapat dikembangkan dengan penambahan cakupan wilayah serta pengembangan pada aspek sikap dan keterampilan melakukan BHD. Luaran akhir dari pengembangan penelitian ini adalah meningkatnya kemampuan masyarakat untuk melakukan BHD pada korban henti jantung yang pada akhirnya dapat menurunkan angka kematian akibat henti jantung. 


\section{UCAPAN TERIMA KASIH}

Terimakasih penulis sampaikan pada pimpinan Akademi Keperawatan Bina Insan Jakarta dan pihak-pihak terkait yang telah membantu terlaksananya penelitian hingga terpublikasi.

\section{DAFTAR PUSTAKA}

American Heart Association Guedelines for Basic Life Support 2015 diunduh dari: https://eccguidelines.heart.org/wpcontent/uploads/2015/10/2015-AHAGuidelines-Highlights-English.pdf

Benoit, J. L., Vogele, J., Hart, K. W., Lindsell, C. J., \& McMullan, J. T. (2017). Passive ultra-brief video training improves performance of compression-only cardiopulmonary resuscitation. Resuscitation, 115, 116119.

https://doi.org/10.1016/j.resuscitation.2 017.04.008

Berdowski, J., Berg, R. A., Tijssen, J. G., \& Koster, R. W. (2010). Global incidences of out-of-hospital cardiac arrest and survival rates: systematic review of 67 prospective studies. Resuscitation, 81(11), 14791487.

https://doi.org/10.1016/j.resuscitation.2 $\underline{010.08 .006}$

Cross, M., et al (2019). Bystander CPR training: is non-classroom based CPR training as effective as a classroom based approach? A systematic review of randomised controlled trials. Rural and Remote Health Vol 19 (3). https://doi.org/10.22605/rrh4772

Dariyo, A (2008). Psikologi perkembangan dewasa muda. Jakarta : Grasindo

Erawati, S. (2015). Tingkat Pengetahuan Masyarakat tentang Bantuan Hidup Dasar (BHD) di Kota Administrasi Jakarta Selatan diunduh dari: http://repository.uinjkt.ac.id/dspace/ha ndle/123456789/29008

Go, A. S. et al (2014). Executive summary: heart disease and stroke statistics2014 update: a report from the American Heart Association. Circulation, 129(3), 399-410. https://doi.org/10.1161/01.cir.0000442 $\underline{015.53336 .12}$

Hung, M. S., Lui, J. C., Lee, D. T., Shiu, I. Y., \& Choi, K. C. (2014). Public knowledge and attitudes towards cardiopulmonary resuscitation in Hong Kong: telephone survey. Hong Kong medical journal= Xianggang yi xue za zhi, 20(2), 126-133. DOI: $10.12809 / \mathrm{hkmj} 134076$

Lumangkun, P. E., Kumaat, L. T., \& Rompas, S. (2014). Hubungan Karakteristik Polisi Lalu Lintas dengan Tingkat Pengetahuan Bantuan Hidup Dasar (BHD) di Direktorat Lalu Lintas Polda Sulawesi Utara. Jurnal keperawatan, 2(2)

Maulidia, R., \& Loura, N. (2019). Hubungan tingkat pengetahuan kognitif dengan kemauan melakukan Cardiopulmonary Resuscitation (CPR) pada remaja di sman malang. Jurnal Kesehatan Mesencephalon, 5(1). http://dx.doi.org/10.36053/mesencepha lon.v5i1.95

Muttaqin, A. (2009). Pengantar asuhan keperawatan klien dengan gangguan sistem kardiovaskular dan Hematologi. Jakarta: Salemba Medika

Notoatmodjo S., 2012, Promosi Kesehatan dan Ilmu Perilaku. Jakarta : Rineka Cipta.

Ozbilgin, Ş., Akan, M., Hanc1, V., Aygün, C., \& Kuvaki, B. (2015). Evaluation of public awareness, knowledge and attitudes about cardiopulmonary resuscitation: report of İzmir. Turkish 
journal of anaesthesiology and reanimation, 43(6), 396. https://dx.doi.org/10.5152\%2FTJAR.2 015.61587

Perkins, G. D., Lall, R., Quinn, T., Deakin, C. D., Cooke, M. W., Horton, J., ... \& Smyth, M. (2015). Mechanical versus manual chest compression for out-ofhospital cardiac arrest (PARAMEDIC): a pragmatic, cluster randomised controlled trial. The Lancet, 385(9972), 947-955. https://doi.org/10.1016/S01406736(14)61886-9

Qara, F. J., Alsulimani, L. M., Fakeeh, M. M., \& Bokhary, D. H. (2019). Knowledge of Nonmedical Individuals about Cardiopulmonary Resuscitation in Case of Cardiac Arrest: A CrossSectional Study in the Population of Jeddah, Saudi Arabia. Emergency medicine international, 2019. https://doi.org/10.1155/2019/3686202

Riggs, M., Franklin, R., \& Saylany, L. (2019). Associations between cardiopulmonary resuscitation (CPR) knowledge, self-efficacy, training history and willingness to perform CPR and CPR psychomotor skills: a systematic review. Resuscitation. 138, 259-272.

https://doi.org/10.1016/j.resuscitation.2 019.03.019

Riskesdas. (2018). Hasil Utama Riset Kesehatan Dasar 2018. Jakarta: Badan Litbangkes, Kemkes RI. diakses dari: https://www.kemkes.go.id/resources/d ownload/info-terkini/hasil-riskesdas2018.pdf (Accesed 12 Maret 2019)

Sasson, C., et al. (2013). Increasing cardiopulmonary resuscitation provision in communities with low bystander cardiopulmonary resuscitation rates: a science advisory from the American Heart Association for healthcare providers, policymakers, public health departments, and community leaders. Circulation, 127(12), 13421350.

Sipsma, K., Stubbs, B. A., \& Plorde, M. (2011). Training rates and willingness to perform CPR in King County, Washington: a community survey. Resuscitation, 82(5), 564-567

Usman, Y dkk (2018). Indonesia's Sample Registration System in 2018. Journal of Population and Social Studies, Volume 27 Number 1, January 2019: $39-52$

Wibrandt, I., Norsted, K., Schmidt, H., \& Schierbeck, J. (2015). Predictors for outcome among cardiac arrest patients: the importance of initial cardiac arrest rhythm versus time to return of spontaneous circulation, a retrospective cohort study. BMC emergency medicine, 15(1), 3. https://doi.org/10.1186/s12873-0150028-3

Wijaya, I. M. S., Dewi, N. L. M. A., \& Yudhawati, N. S. (2016). Tingkat pengetahuan bantuan Hidup dasar pada masyarakat di kecamatan Denpasar Utara. Prosiding Semnas Hasil Penelitian.

http://jurnal.unmas.ac.id/index.php/pro s/article/view/311/275 